\title{
Development and Optimization of Extractives from Astronium urundeuva (allemão) Engl. by Factorial Design
}

\author{
Fabíola Pessoa da Cunha, Luana Janine Lopes da Costa, Ana Josane Dantas Fernandes, \\ Tatiane Pereira de Souza and Luiz Alberto Lira Soares* \\ Departamento de Farmácia; Universidade Federal do Rio Grande do Norte; Av. Gal. Cordeiro de Farias, s/n; \\ 59010-180; Natal-RN - Brasil
}

\begin{abstract}
The purpose of this study was to evaluate the influences from variables of preparation on dry residue and total tannins from macerates of Astronium urundeuva barks. Thus, a $3^{2}$ factorial design was used to study the importance of plant proportion $(10,15$ and $20 \%, w / v)$ and the ethanol concentration $(40,60$ and $80 \%, v / v)$ on the selected response. Mathematical models were fitted according to experimental data. The validated equations were used to generate response surfaces. The analysis of the surfaces showed that the optimum conditions to obtain extractive preparations with high extractive efficiency for tannins were: $10 \%(\mathrm{w} / \mathrm{v})$ of plant with ethanol $40 \%(\mathrm{v} / \mathrm{v})$ as solvent.
\end{abstract}

Key words: Astronium urundeuva, Extraction, Optimization, Factorial Design

\section{INTRODUCTION}

Extractive solutions from the roots of Astronium urundeuva (allemão) Engl. (Anacardiaceae) are widely used in Brazilian traditional medicine for the treatment of several diseases such as antiulcerogenic (Formigoni and Carlini 1988; Rao et al., 1987), analgesic (Viana et al., 2003), antiinflammatory (Meneses et al., 1985; Viana et al., 2003), antioxidant (Demarchelier et al., 1999) and antimicrobial (Raposo et al., 2002). Notwithstanding the active constituents from the roots of A. urundeuva remain undefined; several authors attribute their biological activities to the hydrolysable and condensed tannins, which are the main constituents of the extractive solutions (Formigoni and Carlini 1988; Viana et al., 1997). In this way, this group of substance can be successfully used as a chemical marker for the species.

However, the absence of studies for the standardization of extractive solutions from $A$. urundeuva hampers the reproducibility of the extractives qualities, which could affect the efficiency and safety. Thus, the standardization of plant extractive solutions should be the first step during the technological development of phytopharmaceuticals. The influence of several parameters such as extractive method and technology, type and concentration of solvent, as well as plant concentration, and their influence in the physical-chemical properties of the extractive solutions should be evaluated and quantified (Audi et al., 2001).

Experimental design is a widely used tool for the systematic and effective evaluation of

\footnotetext{
* Author for correspondence: phtech@uol.com.br
} 
modifications of manufacture conditions (Box et al., 1978; Myers and Montgomery, 1995). With this kind of approach, it is possible to create response surfaces that allow the ranking of each variable according to its significance on the studied responses. Therefore, with reduced time and experimental effort, it may be possible to predict what extractive condition will produce a desired or optimum response (Box et al., 1978; Myers and Montgomery, 1995; Canteri-Schemin et al., 2005; Soares et al., 2005).

The aim of this work was to use the experimental design to evaluate the effect of the plant proportion and the ethanol concentration on the dry residue and total tannin content of extractive efficiency of solutions from $A$. urundeuva.

\section{METHODS}

\section{Raw Material}

The raw material was Astronium urundeuva, collected from Alagoinhas - Paraíba (Brazil). The ground material $\left(\mathrm{d}_{50}=0.630 \mathrm{~mm}\right)$ was compared by Thin Layer Chromatographic with an authentic sample (voucher specimen deposited at herbarium of the Universidade Federal do Rio Grande do Norte - Natal/Brazil, under the registration number 3266).

\section{Preparation of the Extractive Solutions}

The extractive solutions were prepared by maceration for four days, using hydroalcoholic mixtures. The influence of plant proportions and ethanol concentration in the efficiency on the extraction of tannins were evaluated by a factorial design $3^{2}$. The factors and levels were selected according to Matos (2004). The matrix of the factorial design is summarized in Table 1.

\section{Dry residue}

Five extractive samples of $20.0 \mathrm{~g}$ from each extractive solution were separately analyzed according to German Pharmacopoeia (Hartke and Mutschler, 1986).

\section{Total tannin content}

For determination of total polyphenol (TP), 5.0 $\mathrm{mL}$ of the extractive solution were diluted with distillated water to $25 \mathrm{~mL}$ Standard Solution (SS). From SS, $5.0 \mathrm{~mL}$ were diluted with distillated water to $25 \mathrm{~mL}$ and the absorbance was determined at $263 \mathrm{~nm}$ using distillated water as compensation solution. The non tannin fraction (NTF) was determined after magnetic stirring of $10 \mathrm{~mL}$ from extractive solution with $150.0 \mathrm{mg}$ of casein during $30 \mathrm{~min}$. The solution was filtered and $5.0 \mathrm{~mL}$ were diluted with distillated water to $25 \mathrm{~mL}$ and the absorbance was determinate at 263 $\mathrm{nm}$ using distillated water as compensation solution.

The total tannin content (TTC) was expressed as gram of Gallic Acid per $100 \mathrm{~g}$ of extractive solution according to the equations below (1 to 3 ). The results represent the mean of three determinations (Costa et al., 2005; Solon et al., 2007).

$$
\begin{aligned}
& \mathrm{TP}=\frac{\mathrm{A}_{1} \cdot \mathrm{DF}}{\mathrm{m} \cdot \mathrm{A}_{1 \mathrm{~cm}}^{1 \%}} \\
& \mathrm{NTF}=\frac{\mathrm{A}_{2} \cdot \mathrm{DF}}{\mathrm{m} \cdot \mathrm{A}_{1 \mathrm{~cm}}^{1 \%}} \\
& \mathrm{TTC}=\mathrm{TP}-\mathrm{NTF}
\end{aligned}
$$

where: $\mathrm{TP}=$ total polyphenols $(\mathrm{g} \%)$; NTF $=$ non tannin fraction $(\mathrm{g} \%)$; TTC $=$ total tannin content $(\mathrm{g} \%) ; \mathrm{A}=$ absorbance (A.U.); $\mathrm{DF}=$ dilution factor; $\mathrm{m}=$ extractive weight and $\mathrm{A}_{1 \mathrm{~cm}}^{1 \%}=$ specific absorption of Gallic Acid (521.1)

\section{Extractive Efficiency}

The extractive efficiency (EE) represents the solvent ability to extract tannin. The EE was used as response and calculated according to equation (4):

$$
\mathrm{EE}=\frac{\mathrm{TTC}}{\mathrm{DR}}
$$

where: $\mathrm{EE}=$ extractive efficiency; $\mathrm{TTC}=$ total tannin content and $\mathrm{DR}=$ dry residue.

\section{The statistic analysis and experimental design}

The experimental matrix was a $3^{2}$ factorial design and it was used to evaluate the influence of plant proportions $(\mathrm{w} / \mathrm{v})$ and ethanol concentration $(\mathrm{v} / \mathrm{v})$ on the efficiency of the extraction of tannins (table 1). The experiments were performed at random and without replication. The dry residue (DR), total tannin content (TTC) and extractive efficiency (EE) were used as responses.

The statistical analysis of the factorial design was performed using the software STATISTICA ${ }^{\circledR} 6.0$ (StatSoft, USA). The experimental data were analyzed by ANOVA and adjusted to a polynomial 
second-order equation (5) by the Partial Less Square (PLS) method (Box et al., 1978; Myers and Montgomery, 1995).

$\mathrm{y}=\mathrm{b}_{0}+\mathrm{b}_{1} \mathrm{x}_{1}+\mathrm{b}_{2} \mathrm{x}_{2}+\mathrm{b}_{11}\left(\mathrm{x}_{1}\right)^{2}+\mathrm{b}_{22}\left(\mathrm{x}_{2}\right)^{2}+\mathrm{b}_{12} \mathrm{x}_{1} \mathrm{x}_{2}+$ $\mathrm{b}_{122} \mathrm{x}_{1}\left(\mathrm{x}_{2}\right)^{2}+\mathrm{b}_{112}\left(\mathrm{x}_{1}\right)^{2} \mathrm{x}_{2}+\mathrm{b}_{1122}\left(\mathrm{x}_{1}\right)^{2}\left(\mathrm{x}_{2}\right)^{2}$

where: $\boldsymbol{y}$ is the response (dry residue, total tannin content or extractive efficency), and $\boldsymbol{b}_{\boldsymbol{0}}$ to $\boldsymbol{b}_{22}$ are the regression coefficients.

\section{RESULTS AND DISCUSSIONS}

The results for dry residue, total tannin content and extractive efficiency are presented in Table 1 . The experimental data were used to generate secondorders models for each response studied. The statistical analyses of the equations are summarized in Table 2.

The proposed mathematical models showed good multiple correlation coefficients $\left(r^{2}\right)$. For both dry residue (DR) and extractive efficiency (EE), the calculated multiple correlation coefficients indicated that more than $99 \%$ of the experimental variance could be explained by the proposed equations. Additionally, for the total tannin content (TTC), the mathematical model described more than $98 \%$ of the experimental behavior. Because the lack-of-fit (LOF) test was not significant, the experimental variations could be attributed only to a randomized error. Thus, the fitted models provide an adequate approximation of the true values and no violations of the model assumptions occurred (Wherlé et al., 1993, 1995; Soares et al., 2005).

Table 1. - Matrix of the factorial design $3^{2}$.

\begin{tabular}{lccccccc}
\hline Exp. & \multicolumn{1}{c}{ Codified variables } & \multicolumn{2}{c}{ Natural variables } & DR (g\%) & TTC (g\%) & EE (TTC/DR) \\
\hline & Plant & Solvent & Plant (w/v) & Solvent (v/v) & & & \\
1 & -1 & -1 & 10 & 40 & 1.13 & 1.73 & 1.53 \\
2 & -1 & 0 & 10 & 60 & 1.15 & 1.51 & 1.31 \\
3 & -1 & +1 & 10 & 80 & 1.01 & 1.24 & 1.23 \\
4 & 0 & -1 & 15 & 40 & 1.66 & 0.89 & 0.53 \\
5 & 0 & 0 & 15 & 60 & 1.67 & 0.63 & 0.38 \\
6 & 0 & +1 & 15 & 80 & 1.47 & 0.50 & 0.34 \\
7 & +1 & -1 & 20 & 40 & 2.14 & 0.41 & 0.19 \\
8 & +1 & 0 & 20 & 60 & 1.62 & 0.36 & 0.22 \\
9 & +1 & +1 & 20 & 80 & 1.86 & 0.26 & 0.14 \\
\hline
\end{tabular}

Exp. $=$ Experiment $;$ DR $=$ dry residue $;$ TTC $=$ total tannin content EE $=$ extractive efficiency

Table 2 - Statistical analysis of the mathematical models.

\begin{tabular}{lcccccc}
\hline Terms & \multicolumn{2}{c}{ Dry Residue $(\mathbf{g} \%)$} & \multicolumn{2}{c}{ Total Tannin Content $(\mathbf{g} \%)$} & \multicolumn{2}{c}{ Extractive Efficiency (TTC/DR) } \\
\hline & Coeffic. $(t$-test) & $\mathrm{F}$ & Coeffic. $(t$-test) & $\mathrm{F}$ & Coeffic. $(t$-test) & $\mathrm{F}$ \\
$b_{0}$ & $1.668\left(210.7^{*}\right)$ & - & $0.664\left(23.6^{*} 8\right)$ & - & $0.399\left(11.7^{* * *}\right)$ & - \\
$b_{1}$ & $0.239\left(42.7^{*}\right)$ & $14488.18^{\mathrm{a}}$ & $-0.576\left(-37.3^{* *}\right)$ & $1390.00^{\mathrm{b}}$ & $-0.587\left(-31.3^{* * *}\right)$ & $981.71^{\mathrm{c}}$ \\
$b_{11}$ & $-0.283\left(-29.2^{*}\right)$ & $422.07^{\mathrm{a}}$ & $0.248\left(9.3^{* *}\right)$ & $86.02^{\mathrm{b}}$ & $0.355\left(10.9^{* * *}\right)$ & $119.86^{\mathrm{c}}$ \\
$b_{2}$ & $-0.097\left(-30.1^{*}\right)$ & $907.06^{\mathrm{a}}$ & $-0.171\left(-11.1^{* *}\right)$ & $123.12^{\mathrm{b}}$ & $-0.092\left(-4.9^{* * *}\right)$ & $24.13^{\mathrm{c}}$ \\
$b_{22}$ & $-0.102(-10.5)$ & $139.02^{\mathrm{a}}$ & $0.009(0.3)$ & 0.11 & $0.025(0.8)$ & 0.58 \\
$b_{12}$ & $-0.039\left(-9.9^{*}\right)$ & $97.09^{\mathrm{a}}$ & $0.086\left(4.5^{* *}\right)$ & $20.57^{\mathrm{b}}$ & $0.064(2.8)$ & 7.71 \\
$b_{122}$ & $0.225\left(-32.8^{*}\right)$ & $1077.13^{\mathrm{a}}$ & - & - & - & - \\
$b_{112}$ & - & - & - & - & - & - \\
$b_{1122}$ & $0.252\left(21.2^{*}\right)$ & $450.38^{\mathrm{a}}$ & - & - & - & - \\
LOF & - & 0.09 & - & 1.14 & - & - \\
$r^{2}$ & 0.9979 & - & 0.9869 & - & 0.9974 & - \\
\hline
\end{tabular}

$t$ - test for $\left.\alpha=0,05\left[\mathrm{t}_{(1,36)}\right]^{*},\left[\mathrm{t}_{(1,18)}\right]^{* *}, \mathrm{t}_{(1,3)}\right]^{* * * ;} \mathrm{F}$ for $\alpha=0,05\left[\mathrm{~F}_{(1,36)}\right]^{\mathrm{a}},\left[\mathrm{F}_{(1,18)}\right]^{\mathrm{b}},\left[\mathrm{F}_{(1,3)}\right]^{\mathrm{c}}$. 
Dry residue (DR), Total Tannin Content (TTC) and Extractive Efficiency (EE)

All responses, observed and obtained, showed a similar profile of influence of studied factors. Either the plant proportion as well as ethanol concentration showed significant influence on the DR, TTC and EE of the extractive solutions. According to the $t$ test for coefficients, plant proportion was the main factor for all responses. The linear term was the principal factor and had a negative effect revealed by a decrease on the TTC and $\mathrm{EE}$ responses, but a positive effect on the DR response. It was followed by the plant proportion quadratic term. The contribution of the secondorder term was interpreted as the presence of curvature and represents the nature of the response surface system (maximum, minimum or saddle system), indicating that there was optimum conditions. Thus, the negative signal for quadratic terms revealed the convex form of the curve, as was observed for plant proportion and DR (Fig. 1). On the other hand, the positive signal for quadratic terms demonstrated the concave form of the curve, as was observed for plant proportion and TTC or EE (Fig. 2 and 3) (Myers and Montgomery, 1995).

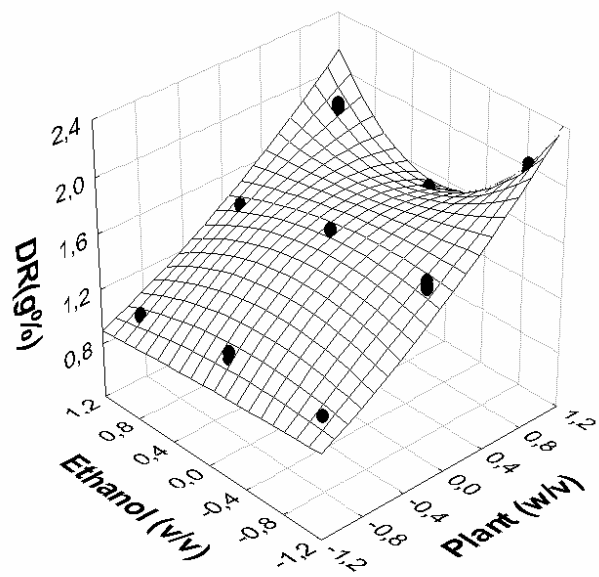

Figure 1 - Effects of plant proportions and ethanol concentrations on the dry residue (DR) of the extractives.

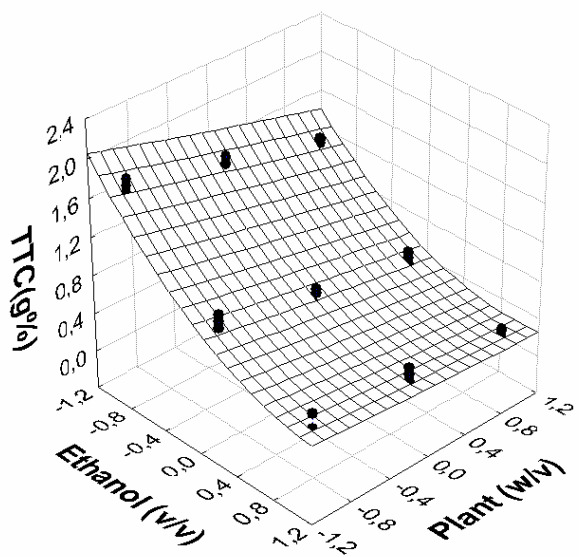

Figure 2 - Effects of plant proportions and ethanol concentrations on the total tannin content (TTC) of the extractives. 


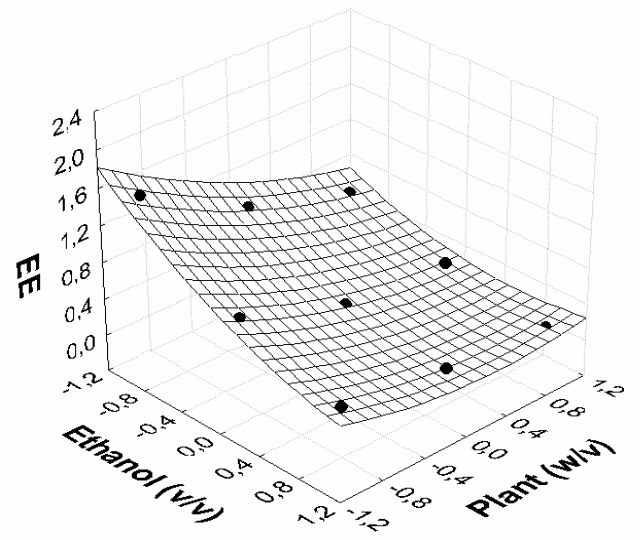

Figure 3 - Effects of plant proportions and ethanol concentrations on the extractive efficiency (EE) of the extractives.

The response surfaces indicated the TTC and EE responses were inversely proportional to the plant proportion. This fact could be explained through the solvent saturation, the increase of drug proportion seemed to reduce the solvent efficiency on tannin extraction, but on the other hand this did not affect the dry residue of the extractive solution, which was directly proportional to the plant proportion. The DR was composed for all the soluble solids presents in the extractive solution, therefore the tendency was that the larger plant proportion were the larger solids extracted. However, a specific group of substances was dependent of the solvent efficiency (List and Schimdt, 1989). Comparing Figure 1 with Figure 2 , it was found that the higher DR, the lesser was the TTC, which mean that there was a competition of tannins and other substances for the solvent.

Concerning the ethanol concentration, there was a minor influence on the responses. Although a statistical importance was found for the ethanol concentration, only a significant technological influence was observed for DR response (Fig. 1). Due to interaction between the factors, quadratic behaviors for ethanol were observed at intermediary and higher levels of plant proportion. However, the quadratic influences of ethanol disappeared for both other responses, remaining only a slight linear and negative influence (Fig. 2 and 3).

\section{CONCLUSIONS}

The factorial design and response surface methodology were used satisfactorily to evaluate the influence of plant proportion and ethanol concentration on the properties of extractive solutions from $A$. urundeuva. The statistical analysis performed by the multiple coefficients of regression, $t$-test for the coefficients and analysis of variance showed the adequacy of the mathematical models, providing reliance to the surface generated. Thus, the study demonstrated that the plant proportion affected all the responses decreasing their values, while the ethanol concentration showed a slight influence with similar profile to the plant proportion. To conclude, the optimum condition to prepare the extractive solutions of $A$. urundeuva with maximum dry residue and total tannin content (higher extractive efficiency), was found using 10 $\%(\mathrm{w} / \mathrm{v})$ of plant and ethanol $(40 \% ; \mathrm{v} / \mathrm{v})$ as the extractive solvent. At these conditions, the extractive showed dry residue of $1.13 \%$, total tannin content of $1.73 \%$ and efficiency of $1.53 \%$.

\section{RESUMO}

O objetivo deste trabalho foi avaliar as influências de variáveis de preparação de macerados das cascas de Astronium urundeuva sobre resíduo seco e teor de taninos totais. Desta forma, um desenho fatorial do tipo $3^{2}$ foi empregado para avaliar a importância da proporção de planta $(10,15$ e 20 $\% ; \mathrm{m} / \mathrm{v})$ e da concentração de etanol $(40,60$ e 80 $\% ; \mathrm{v} / \mathrm{v})$ sobre as respostas eleitas. Modelos matemáticos foram ajustados aos dados experimentais. As equações validadas foram 
usadas para gerar superfícies de respostas. A análise das superfícies demonstrou que as condições ótimas para obtenção de preparações extrativas com elevada eficiência extrativa de taninos foram: $10 \%(\mathrm{~m} / \mathrm{v})$ para planta e etanol 40 $\%(\mathrm{v} / \mathrm{v})$ como solvente.

\section{ACKNOWLEDGEMENTS}

The authors gratefully acknowledge PPGCFUFRN and PIBIC/CNPq-UFRN.

\section{REFERENCES}

Audi, E. A., Campos, E. J. V., Rufino, M., Cortez, D.G., Bersani-Amado, C. A., Soares, L. A. L., Petrovick, P. R. and Mello, J. C. P. (2001). Petiveria alliacea L.: Plant drug quality control, hydroalcoholic extract standardization and pharmacological assay of lyophilized extract. Acta Farmaceutica Bonaerense, 20 (3), 225-232.

Box, G. E., Hunter, W. G. and Hunter, J. S. (1978). Response surface methods. In- Statistics for Experimenters. Box G. E., Hunter, W.G., Hunter, J. S., (Eds.). Wiley, New York, pp. 510-539.

Canteri-Schemin, M. H., Fertonani, H. C. R., Waszczynskyj, N. and Wosiacki, G. (2005). Extraction of pectin from apple pomace. Brazilian Archives of Biology and Technology, 48 (2), 259-266.

Costa, L. J. L., Egito, E. S. T., De Souza, T. P., Soares, L. A. L. (2005). Taninos em macerados de Schinus terebinthifolius (RADDI): Avaliação de agentes precipitantes. Presented at IV COPERFARMA: Congresso Pernambucano de Farmacêuticos Encontro Internacional de Ciências Farmacêuticas, 27-30 april, Recife, Brazil.

Desmarchelier, C., Romao, R. L., Coussio, J. and Ciccia, G. (1999). Antioxidant and free radical scavenging activities in extracts from medicinal trees used in the 'Caatinga' region in northeastern. Brazil. Journal of Ethnopharmacology, 67, 69-77.

Formigoni, M. L. O. and Carlini, E. A.(1998) Efeitos dos decoctos de aroeira da praia (Schinus terebinthifolius Raddi) e da aroeira do sertão (Astronium urundeuva Engl) sobre a úlcera experimental em ratos. In: Simpósio de plantas medicinais do Brasil, 10, 1988, São Paulo. Resumos..., São Paulo, 1988.

Hartke, K. and Mutschler, E. (1986). Deutscher Arzneibuch. 9 Ausgabe. Kommentar. Stuttgart:WVG, pp 305-307.

List, P. H. and Schmidt, P. C. (1989). Phytopharmaceutical Technology. Boca Raton:CRC.
Matos, F. J. A. (2004). Constituintes químicos ativos e propriedades biológicas de plantas medicinais brasileiras. Fortaleza: Editora UFC, pp 86-90.

Menezes, A. M. S., Rao, V. S. N. and Fonteles, M. C. (1985). Antiinflamatory activity of Astronium urundeuva: possible mechanism envolved. Brazilian Journal of Medical Biology Reearch, 18, 861-864.

Myers, R. H. and Montgomery, D. C. (1995). Response Surface Methodology: Process and Product Otimization Using Designed Experiments, New York: Willey.

Rao, V. S. N., Viana, G. S. B. V., Menezes, A. M. S. and Gadelha, M. G. T. (1987). Studies on the antiulcerogenic activity of Astronium urundeuva Engl. II. Aqueous extract. Braz. J. Med. Biol. Res. 20, 803805.

Raposo, M. J., Melo, Jr. E. J. M., Neto, J. A. L., Diniz, M. F. A., Marcelino, Jr. C. A. C. and Sant'ana, A. E. G. (2002). Medicinal plants in the healing of dry socket in rats: microbiological and microscopic analysis. Phytomedicine 9, 109-116.

Soares, L. A. L., González Ortega, G., Petrovick, P. R. and Schmidt, P. C. (2005). Optimization of Tablets Containing a High Dose of Spray-Dried Plant Extract: A Technical Note. AAPSPharmSciTech 6(3), 368-371.

Solon, L. G., Costa, L. J. L., Almir G Wanderley, A. G., Soares, L. A. L., De Souza, T. P. (2007). Avaliação de agentes complexantes na quantificação de taninos totais em soluções extrativas de Schinus terebinthifolius RADDI e Psidium guajava L. Biofarma, 2(4), 275-281.

Viana, G. S. B. V., Bandeira, M. A. M. and Matos, F. J. A. (2003). Analgesic and antiinflammatory effects of chalcones isolated from Myracrodruon urundeuva Allemao. Phytomedicine 10, 189-195.

Viana, G. S. B. V., Bandeira, M. A. M., Moura, L. C., Souza, M. V. P., Matos, F. J. A. and Ribeiro, R. A. (1997). Analgesic and antiinflamtory effects of the tannin fraction from Myracrodruon urundeuva Fr. All. Phytotherapy Research, 11, 118-122.

Wehrlé P., Nobelis P., Cuiné A. and Stamm A. (1993). Response surface methodology: an interesting statistical tool for process optimization and validation. Example of wet granulation in a highshear mixer. Drug Development and Industrial Pharmacy, 19, 1637-1653.

Wehrlé P., Magenheim P. and Benita S. (1995). The influence of process parameters on the PLA nanoparticle size distribution evaluated by means of factorial design. European Journal of Pharmaceutics and Biopharmaceutics, 41, 19-26.

Received: August 31, 2006; Revised: May 22, 2007; Accepted: June 23, 2008 